\title{
REVIVING ABANDONED RESERVOIRS WITH HIGH-PRESSURE AIR INJECTION: APPLICATION IN A FRACTURED AND KARSTED DOLOMITE RESERVOIR
}

\author{
Semi-Annual Report \\ Reporting Period Start Date: April 1, 2004 \\ Reporting Period End Date: September 1, 2004
}

Principal Authors: Robert Loucks (Co-PI), Steve Ruppel (Co-PI), Julia Gale, Jon Holder, Jon Olson

Date Report Issued: January 20, 2005

DOE Award Number: DE-FC26-02NT15442

Bureau of Economic Geology

John A. and Katherine G. Jackson School of Geosciences

The University of Texas at Austin

Box X, University Station

Austin, TX 78713-8924

and

Goldrus Producing Company

17314 State Highway 249, Suite 300

Houston, Texas 77064-1140

January 2005 


\section{DISCLAIMER}

This report was prepared as an account of work sponsored by an agency of the United States Government. Neither the United States Government nor any agency thereof, nor any of their employees, makes any warranty, expressed or implied, or assumes any legal liability or responsibility for the accuracy, completeness, or usefulness of any information, apparatus, product, or process disclosed, or represents that its use would not infringe privately owned rights. Reference herein to any specific commercial product, process, or service by trade name, trademark, manufacturer, or otherwise does not necessarily constitute or imply its endorsement, recommendation, of factoring by the United States Government or any agency thereof. The view and opinions of authors expressed herein do not necessarily state or reflect those of the United States Government or any agency thereof. 


\begin{abstract}
The Bureau of Economic Geology (BEG) and Goldrus Producing Company have assembled a multidisciplinary team of geoscientists and engineers to evaluate the applicability of high-pressure air injection (HPAI) in revitalizing a nearly abandoned carbonate reservoir in the Permian Basin of West Texas. The characterization phase of the project is utilizing geoscientists and petroleum engineers from the Bureau of Economic Geology (BEG) and the Department of Petroleum and Geosystems Engineering (both at The University of Texas at Austin) to define the controls on fluid flow in the reservoir as a basis for developing a reservoir model. This model will be used to define a field deployment plan that Goldrus, a small independent oil company, will implement by drilling both vertical and horizontal wells during the demonstration phase of the project. Additional reservoir data were to be generated during the demonstration phase to improve the accuracy of the reservoir model.

The demonstration phase has been delayed by Goldrus because of funding problems. Since the first of the year, Goldrus has been active in searching for partners to help finance the project. After financial support is obtained, the demonstration phase of the project will proceed. Since just after the beginning of the year, BEG has curtailed project activities and spending of DOE funds except for the continued support of one engineering student. This student has now completed his work and his thesis was reported on in the last semi-annual report.

We plan to recommence our work on the project as soon as the operator obtains necessary funding to carry out the demonstration phase of the project. In order to complete all activities specified in the proposal, we requested and received an extension of the project to September 30, 2005. We are confident that Goldrus will obtain the necessary funding to continue and that we can complete the project by the end of the extension data. We strongly believe that the results of this study will provide the impetus for a new approach to enhanced oil recovery in the Permian Basin and elsewhere in the United States.
\end{abstract}




\section{TABLE OF CONTENTS}

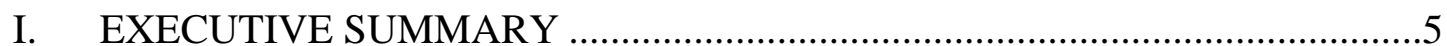




\section{EXECUTIVE SUMMARY}

The demonstration phase has been delayed by Goldrus because of funding problems. Since the first of the year, Goldrus has been active in searching for partners to help finance the project. After financial support is obtained, the demonstration phase of the project will proceed. Since just after the beginning of the year, BEG has curtailed project activities and spending of DOE funds except for the continued support of one engineering student. This student has now completed his work and his thesis was reported on in the last semi-annual report.

We plan to recommence our work on the project as soon as the operator obtains necessary funding to carry out the demonstration phase of the project. In order to complete all activities specified in the proposal, we requested and received an extension of the project to September 30, 2005. We are confident that Goldrus will obtain the necessary funding to continue and that we can complete the project by the end of the extension data. We strongly believe that the results of this study will provide the impetus for a new approach to enhanced oil recovery in the Permian Basin and elsewhere in the United States. 